\title{
Balkanologie
}

Balkanologie Revue d'études pluridisciplinaires

Vol. $16 n^{\circ} 1 \mid 2021$

Au-delà de la "route des Balkans ": mondes sociaux des circulations

\section{City Museums and Local Integration Policies: The Case of the Volos City Museum}

Musées de la ville et politiques d'intégration locale : le cas du musée de la ville de Volos

\section{Eleni Sideri}

\section{OpenEdition}

\section{Journals}

Electronic version

URL: https://journals.openedition.org/balkanologie/2804

DOI: 10.4000/balkanologie.2804

ISSN: 1965-0582

\section{Publisher}

Association française d'études sur les Balkans (Afebalk)

\section{Electronic reference}

Eleni Sideri, "City Museums and Local Integration Policies: The Case of the Volos City Museum",

Balkanologie [Online], Vol. $16 n^{\circ} 1$ | 2021, Online since 01 June 2021, connection on 03 October 2021. URL: http://journals.openedition.org/balkanologie/2804 ; DOI: https://doi.org/10.4000/balkanologie. 2804

This text was automatically generated on 3 October 2021 .

(c) Tous droits réservés 


\section{City Museums and Local Integration Policies: The Case of the Volos City Museum}

Musées de la ville et politiques d'intégration locale : le cas du musée de la ville de Volos

Eleni Sideri

1 One of the people I interviewed for my research for the Volos City Museum was Harir, a middle-aged man from Pakistan. Although Harir owned his own small tapestry factory in a city near Lahore, he had to leave it due to political instability in the early 2000 s. After spending a couple of years in a rural area just outside Athens, he moved to Volos. He rented a house in Nea Ionia and opened a small shop selling ethnic food products. Entrepreneurial activity facilitated the procedure for a residence permit. In our meetings, he confessed that the moments he treasured most in the city were the times when he shared fruit with his friends and neighbours at the doorstep of his house. When I asked him who these friends were, he replied: a couple of Roma families and their kids - and explained the pleasure of the moment. The kids often competed in spitting the tangerine or melon (depending on the season) seeds as far as possible. Then I asked in what language they communicated. He said that they did not speak with words. His narrative was one of my favourite stories and I was wondering how the visitors of the new Volos City Museum would react to it.

City museums are something new for Greece. The project for generating a collection of oral histories for one in Volos, in collaboration with the Department of History, Archaeology and Social Anthropology at the University of Thessaly, was an innovation in several senses. The museum-form was new, the university collaboration was new, and so was the museum's agenda. This agenda aspired at "highlight[ing] the city's social structure, economic and productive activities and its relationship with its surroundings within a local, regional, national, Mediterranean, European and global framework." ${ }^{1}$ The connection of a local museum to different layers of history (local, 
regional, European) and the stress on social history was meant to make a difference, and to make the city more inclusive.

3 At the time of the museum's foundation, Greece was experiencing economic crisis, and this was transformed shortly into a humanitarian crisis. The far right gained ground in Greece, even in the city of Volos, with its deep connections to refugees and migration. This framework emphasised how the museum might play a part in the new role assigned to European cities by the European Union (EU) as receivers of a great number of immigrants who need to become and to feel included. How do European cities consider their new role? What policies do they develop? As Sarah Hackett and Maria Schiller ${ }^{2}$ underlined in their comparative study of integration policies in different European cities, we still need to study the ways migration flows, integration policies and diversity interweave at the level of city policies. My paper explores one aspect of this approach regarding city cultural policies and integration.

4 Local policies have gained importance due to EU decentralisation efforts since the 1990s. In Greece, the socio-political weaknesses of Greek politics did not encourage the independence of local politics from the central political scene. The increasing scarcity of resources since 2008 prevented decentralisation even further. Concurrently, the growing populism in the Greek public arena made migration and integration even more central issues in public discourse, both nationally and locally.

The paper will examine the opening of the Volos City Museum in connection with integration policies and decentralisation. It will also explore how the museum's collection and its exhibitions tried to launch a more inclusive and participatory agenda that pluralised the city's history. Nevertheless, the paper will also show the limits of such an undertaking in the local context. My engagement with the museum took place in a research project of almost two years (2013-2015) which included fieldwork and interviews with immigrants who had arrived in Volos since the 1990s. The paper is based on that research but also on an analysis of the subsequent exhibitions since 2015 until 2020, the museum's website and published material.

\section{Memory, Museums and Migration}

6 According to Rosa Tamborrino, ${ }^{3}$ who compared several city museums in Europe, city museums, their collections and the way they approached the past introduced a new way of producing memory space within cities. The decision for such a museum is always political and engages different agendas, scales and actors. For years, urban memory was tied to nation-building. As Andromache Gazi underlined, ${ }^{4}$ museums were always part of a framework which included school history, monuments, textbook, high arts and cinema, and shaped what we call cultural memory. In other words, museums participate in the institutionalisation of memories through cultural discourses and practices that are aimed at disseminating specific meanings.

7 Since the 1970s, there was a shift towards a more inclusive agenda in the European cultural policies. Memories often silenced or marginalised (of social, racial, ethnic, sexual, religious, or other minority groups) became central in museum collections. In that way, the all-encompassing narrative of national history was contrasted to specific social and historically-contextualised experiences. The new take was considered as part of a political endeavour to democratise memory in Europe. This shift regarding policies 
coincided with a new understanding of the museum collections. In other words, the democratisation of memory interwove with a new musicological agenda.

Gaynor Kavanagh argued ${ }^{5}$ that museums traditionally shaped history by ordering traces of the past into a coherent narrative for all visitors, and that this generated a seemingly shared and homogenous experience. But within the above shift, museums developed a new strategy trying to evoke each visitor's personal experiences. The change reflected the passage from dominant hegemonic narratives to an experiential relation among place, memories and community. In parallel, the increasing recognition of multiculturalism in the 1980s and 1990s within the European societies encouraged the recognition of diverse memories and voices. This shift was a political as well as an economic project.

Since the 1970s, the emerging neo-liberal politics (structural readjustment focusing on market-oriented economies, absence of national subsidies and trade protectionism) put an end to post-war state protectionism in the cultural sector. Culture and arts turned into significant economic resources for the regeneration of the decaying industrial economies of the cities and into a political tool for more inclusive cultural politics. ${ }^{6}$ Furthermore, state financing for arts gradually shrank allowing new stakeholders (international and supranational organisations, private sector, local authorities) to become involved. ${ }^{7}$

In the 1990s, culture through spectacles, festivals, galleries, conservation of historical buildings or neighbourhoods' gentrification became key sources of capital for the economies of urban centres. Cultural heritage, city branding and tourism made urban economies more open and interdependent on the global economy. In this context, city museums - apart from pluralising memory - contributed to developing urban economies through extending the touristic season as well as enhancing and revitalising zone markets in less developed areas. ${ }^{8}$ How did these changes influence the decision for the construction of a city museum in a medium-size city in Greece?

11 Joining the European Economic Community (EEC) in 1981, Greece embarked on modernising its administration by stressing the need for decentralisation and more efficient governance. For example, the opening of new institutions of higher education in the Greek periphery, like the University of Thessaly in central Greece (1984), was part of this new agenda. ${ }^{9}$ The first wide administrative reorganisation took place in 1997 (Law 2539/1997). ${ }^{10}$ The reform had as its primary objective the modernisation of the Greek administration, but also transparency in the management of local politics. In addition, the reform combined financial and administrative independence with the regional development of Greece through major public works of infrastructure in the peripheries of the country. The second wave of reforms took place in 2010 (Programme Kallikratis, Law 3852/2010). The goal was the increase of citizens' participation in local politics. There was strong resistance to this reform. The reactions were related to immigration.

12 These administrative transformations enhanced the transition, among museums, from the production of narratives about territorialised, culturally bounded "Greek" communities to those about locality. ${ }^{11}$ Like museums elsewhere, Greek museums were challenged to read historical heritage not as recollection of a national past; instead, they themselves became the space where historically experienced memories were brought forward to depict different, even controversial, lived pasts. ${ }^{12}$ This change needed to contextualise the "individual," "private/domestic" and often "marginal" in 
wider "collective" and "public" histories and discourses..$^{13}$ Oral histories became a central part of city museum exhibits. In Volos, to great extent, the oral histories collected by the soon-to-be museum concerned refugee and immigrant populations and their integration.

\section{Volos: An Immigrant City}

13 At the end of the nineteenth century, the city of Volos began to develop mainly as a trading post. With the annexation of Thessaly to the Greek state (1881), Volos and its port began to attract populations from the mountain villages of Pelion and neighbouring areas. ${ }^{14}$ The city gained the status of municipality in $1883(31 / 3 / 1883$ Decree 126). However, it was the Asia Minor Catastrophe (1922) that shaped the wider urban area of Volos with the development of new residential areas to host the refugees -like Nea Ionia (in which 5,000-6,000 people initially settled). ${ }^{15}$ The refugee labour was channelled into the industrialisation of the city, ${ }^{16}$ and in 1947, a royal decree separated the urban area of Volos into two independent municipalities: the working-class municipality of Nea Ionia, ${ }^{17}$ and the more bourgeois city of Volos. In that way, it was believed that Volos would not fall into the hands of the Communists who were popular among workers of refugee origin. The Second World War, the Civil War, and then the catastrophic earthquakes of 1955 halted economic growth until the later 1950s and 1960s.

14 The 1990s were considered a transition period for Greece. ${ }^{18}$ Until then, the country had considered itself as a migrant-sending country (the peak periods were the inter-war period, 1920-1930, and the post-war period, 1950-1970). This process began to reverse in post-junta Greece (since 1974), but it was the fall of the Berlin Wall that propelled more migrants to Greece from the Balkans and the former Soviet Union.

Today, the municipality of Volos covers $387.14 \mathrm{~km}$ and has almost 144,449 inhabitants (last census of 2011), making it one of the ten largest municipalities of Greece. ${ }^{19}$ According to the last census of 2011, ${ }^{20}$ there were more than 5,500 non-ethnic Greek inhabitants living in the area (nomos) of Magnesia, and almost 3,000 in the municipality of Volos. The majority, almost 4,000, are Albanian (1,500 of whom are in the municipality of Volos), ${ }^{21}$ less than 500 are from Bulgaria, almost 100 are from the former USSR and the rest from other Asian and African countries (especially from Pakistan, China and Nigeria). These numbers, however, should be treated with caution, as immigrants are often hesitant to register or take part in surveys.

There are two additional notes to make about immigrant populations and activities outside the industrialised urban core areas. The first note is that the wider area of Magnesia also hosted two centres for unaccompanied minor children. There was one in the village of Makrynitsa in the mountain of Pelion and the other one in the coastal town of Agria, seven kilometres from Volos. The second note is that immigrants from West Africa (mostly from Nigeria) and from Asia (mostly from Pakistan, Afghanistan and Bangladesh) offered rural seasonal labour often complemented with menial jobs on the weekends or during the winter (e.g. cleaning cars, selling herbs).

17 Finally, even as tensions over immigration expanded after 2008, Volos has continued to play host to new waves. In 2015, a new Open Hospitality Refugee Centre was built almost ten minutes from the centre of Volos, in Moza, in 2016. ${ }^{22}$ Moza used to be an old car dealership. As a camp, it has the capacity to host about 130 individuals. These 
arrived mainly from Arab and Kurdish speaking areas (Syria, Iraq, Kurdistan), and consisted to a great extent, of children and women. ${ }^{23}$ Publications in the local press postulated mixed reactions of the local population to the presence of refugees, but there has been no major resistance. ${ }^{24}$

\section{Integration and Vulnerability}

18 A research project carried out by the University of Thessaly in 2004-2007, which conducted interviews with Albanian and Bulgarian immigrants living in Volos, showed that many of these immigrants, despite their regularisation, continued to express complaints regarding the will of their employers to employ them legally. In this context, the economic recession that followed made them even more susceptible to exploitation. In terms of formal relations with the authorities, no institution seemed to have helped them: the only institution present in their narratives was the police - from whom they reported violence - as their accounts of integration often referred to the first period of their arrival in the mid-1990s, when migration was still handled by the Greek police.

19 These immigrants were helped to adapt to the city by informal networks of employers, co-workers, neighbours and - especially for the second generation - education. By the early 2000s, mobilisation among immigrants was also emerging. For example, the Albanian immigrants founded two associations (Illyria and the Association of Young Albanian Scientists). Similarly, the Edo immigrants from Nigeria organised an association in 2008 which could serve as a meeting point for the community, ${ }^{25}$ to "help our people to have a home," as a member of the board told me.

20 The politicisation of immigration in the 1990s was linked to the growing numbers of immigrants and the reshaping of the public sphere. Under the growing pressure of the EU political and economic agendas immigration became a focal point as central governments tried to "regain popular legitimacy by articulating populist ideas and sentiments concerning cultural identity." ${ }^{26}$ When Greece entered recession in 2008, anti-immigration discourses made debates about identity the centre of public interest, drawing attention away from the political and economic agenda. Moreover, the growing lack of a strong political will to back up any changes regarding immigrants' rights at the national level increased the reluctance of local authorities to implement them.

21 Anti-immigration sentiments continued to build in the second decades of the 2000s. The electoral success of Golden Dawn ${ }^{27}$ (the extreme right party) in 2012 generated a reaction from mainstream conservative political parties who tried to regain their popularity by bringing back voters from the extreme right by increasing their own rigidity over social and immigration issues. In the local elections of 2014, a new local government was elected in Volos, transferring the power from a socialist-leftist coalition to the conservative party. ${ }^{28}$ Moreover, frequent changes of the legal framework facilitated their lack of application; local administrations hesitated to implement innovations when they foresaw possible controversy among local voters, and it became convenient to claim that they could not keep up with the changing laws. 29

The economic crisis also had a direct impact on the economic lives, legal status and social integration of immigrants. Foreign workers, who were over-represented in the 
construction and tourism sectors, suffered disproportionally from the economic crisis. As a result, a considerable number of immigrants preferred to return to their original countries or, if they had the chance, to move to another European country. Unemployment also changed legal status: those who were unable to renew their work permits ceased to be "documented" and became "undocumented" immigrants. Immigration policies that local authorities, like that in Volos, had developed in response to immigrants' needs before the crisis, such as immigrant councils, language courses and cultural activities to promote interculturalism (festivals, theatre) came under review..$^{30}$ Relations between local administrations and immigrants changed, too, as the austerity measures and enforcement of the economic Memorandum in 2010 limited the resources of local authorities and reshaped local power relations.

\section{Volos City Museum}

In this context, the Volos City Museum envisioned to include and consider the diverse, ever-changing history of Volos in connection to refugee and migration flows. "The history of Volos is nothing else than the history of its inhabitants," ${ }^{31}$ stated Aigli Dimoglou, a local historian who oversaw the city archives, at the inauguration of the museum's first exhibition..$^{32}$ This inclusivity is characteristic of city museums. However, interesting observations can be made when we take a closer look at what this inclusivity meant and who was included.

Perhaps it should be noted that immigrants themselves were sceptical from the outset. When I shared my excitement for the opening of the museum with olga, who came from Novorossiysk in South Russia, she expressed doubts. Olga herself had worked in a local museum before leaving Russia, and in Volos, she was involved with a dance association and several other cultural activities regarding immigrants from the former Soviet Union (both Pontic-Greeks and other ethnicities). When I urged her to meet people from the museum in case they needed her expertise, she asked doubtfully, "Would they need my help?". I insisted that the museum needed the collaboration of Volos's migrant communities, but she just smiled: "We will see." She guessed that the museum would be another expression of the Greek state and bureaucracy. This kind of mistrust made the museum's mission for inclusivity difficult and urgent.

Volos is a city that always fostered special attention to its own history. I remember that when I arrived in Volos for my first job as teaching assistant in 2007, what impressed me the most was the number of people who read the local, and not the national, press. The library of Volos and its Municipal Center for History and Documentation started operating in 1992. Its goals were the collection, administration, digitalisation and promotion of any kind of documents concerning Volos's past. At the same time, they published a three-monthly review, En Volo (In Volos), on cultural and historical aspects of the city. The early industrialisation of the city and its connection to international trade due to the port and the railroad, which contributed to the formation of a bourgeois class, must have played a significant factor on this local historical consciousness.

The museum was planned to complement the resources on local history taking a more open approach. It was to be hosted in a building already owned by the municipality, ${ }^{33}$ and was to have a collection based on donations (photographic archives and material culture) already made to the Center for History and Documentation, as well as a 
collection of oral histories. To collect the oral histories, the local authorities decided to collaborate with the academic community. In this sense, the museum was a joint initiative that overcame a number of economic difficulties (budget restrictions, delays in the disbursement of the funding).

The University of Thessaly (Department of Architecture and Department of History, Archaeology and Social Anthropology) and Aristotle University of Thessaloniki (Department of Architecture) developed a research programme, DEMUCIV, Designing the Museum of the City of Volos (2011-2015). The programme's goal was to develop historical and anthropological research, which could postulate the city's economic, cultural and social histories, as well as its relation to a local, national, Mediterranean, European and global framework. Moreover, the project tried to develop and apply innovative technologies to present and propagate its findings.

The area where the museum was founded is called Palea (old) and the building was an old tobacco storehouse (Kapnapothiki Papandou) until the 1920s, which also hosted refugees from Asia Minor when they first arrived. Palea was the first and the oldest settlement of the city of Volos, and bears traces of prehistoric times, a Byzantine castle and a small market near the port. During the twentieth century, Volos developed along the beach of the Argonauts, where all the business and administrative functions of the new city were concentrated. Thus, Palea was degraded aesthetically and became isolated from the rest of the city. As a result, the area was reduced from a historical centre to a peripheral area. ${ }^{34}$

Since the 1990s, a process of gentrification started in the area, including the opening of new companies related to transportation and small-size enterprises related to entertainment (taverns, bars, take always), which complemented the old artisans' shops (now renovated), along roads that were re-zoned for pedestrians only. The changes altered the physiognomy of the hitherto undervalued neighbourhood of Palea, but maintained its special character and historical heritage from Byzantine and Ottoman times..$^{35}$

I worked (between 2013-2015) on the collection of oral histories as part of my postdoctoral research on urban memory among immigrants who arrived in Volos since the 1990s. The immigrants with whom I worked originated from Asia (Chinese, Afghans, Pakistanis and Bangladeshis) and Africa (Nigerians). Migrations and crises were two fundamental categories, both for the museum and for our university research. Migrants were depicted through the collection of stories from various categories of older and new immigrant communities. Crisis was addressed in relation to moments of economic and social transformation of the city, for example, wars, natural disasters and economic plights. Moreover, as the oral interviews and the archival research postulated, these moments of crisis in the history of the city related to different forms of migration. This connection between economic crisis and migration was reflected in the first exhibition hosted in the museum in 2014. ${ }^{36}$

31 The exhibition was dedicated to the division that set up the modern history of the municipality of Volos. The split between Volos and Nea Ionia reflected economic and political divisions that produced Volos as a city. It was visited by a total of 50,000 visitors, ${ }^{37}$ an unexpected number for a provincial city museum. Reviewing the collection and the museum itself in 2020, one of the most respected newspapers in Greece, Kathimerini underlined, "All the people who worked, sang, struggled and sacrificed, are all there [in the collection]. ${ }^{38}$ In this sense, it seemed that the Volos City 
Museum was more than successful. It captured a history and created an experience of that history for the visitor.

Nevertheless, other museums featuring immigration have been criticised for this very success in creating "experience." In their comparative research on museums in Germany and Belgium (Antwerp, Bremerhaven and Hamburg), Katja Pelsmaekers and Tom Van Hout postulate an argument that museums of immigration are a creation of post-industrial capitalism's economy of experience..$^{39}$ The museum exhibits are intended to produce "empathy," especially for less visible histories, but they commodify immigration to produce a marketable, less complex and superficial "experience" of tough issues and painful stories. ${ }^{40} \mathrm{Could}$ we find this contradiction in Volos too?

\section{Exhibiting History}

The first exhibition in 2014 (and its 3D representation) was entitled Volos-Nea Ionia: That Far and that Near. It was divided into different sections. The first section, "Urban Space," represented both the space the refugees from Asia Minor encountered when they arrived in 1922, and also the urban space they themselves produced after years of working in the new homeland (neighbourhoods, houses). The second section, "Labour," highlighted the human labour of the newly arrived population and their efforts to make a living.

The third section illustrated the history of housing. It examined the accommodation of new residents in the past and the gradual formation of neighbourhoods where social and intercultural communication took place. The exhibition continued with a section dedicated to people and stories concerning leisure and entertainment, city life and football. Football and the dominant opposition between two football teams - Niki Volou (Nea Ionia's team) and Olympiacos Volou (Volos's team) - were very important for the representation of the cultural life of the two municipalities. Besides, the election of the new mayor showed how much football still plays a role in local politics because he was widely known from having been president of the local football team.

As a result, the exhibition showed that, although immigration was salient for the new museum's collection and its first exhibition, the latter referred only to flows of the past that concerned the ethnic Greek population with a high degree of proximity to the Greek "high culture." The topic of crisis and immigration was brought up in the exhibition, not in relation to the current crisis, but in regard to the political and economic crisis that the city of Volos and the rest of the country faced in 1922 after the Greek-Turkish War and the exchange of population between the two countries. The inflow of refugees was represented as a gradual process of integration that enriched the city's memory, economy, culture and history.

In this "first crisis," it was ethnic Greek refugees who arrived in a city in need of cheap labour for its industrial production. These immigrants were recognised, to a great extent, as Greek citizens. The impact of this in-flow on the municipal institutions was great, as it reinforced the labour class of the city leading to the formation of the two municipalities, Nea Ionia and Volos, ${ }^{41}$ as discussed above. This crisis caused by the war between Greece and Turkey eventually contributed to the development of the country and the city. The crisis of 1922 was depicted as a transformative moment with which Greek society and Volos coped, mostly through individual initiatives and ingenuity. It 
seemed that the same qualities were expected from more recent immigrants, neglecting or minimising the responsibility of central and local governments regarding integration.

In the collection, there were very few references to the present and to the new migrations in the 1990s. One of the explanations the museum gave was that many new immigrants did not give their consent to use their testimonies in public, or that it was not possible to translate their stories into Greek in such a short period of time and without resources (professional translators). However, it seems that the choice of the topic of this inaugural exhibition was not without links to the influences of the Greek economic and political crisis.

The museum was a local initiative that tried to re-read Volos's history in a more inclusive and less formal way. Despite the context of economic and political crisis both at local and national levels, the museum opened its doors due to a collaboration of forces which lay outside the remit of the central authority: that between the local government, the University of Thessaly and the EU. Moreover, the inhabitants of Volos contributed by sharing their personal stories and memories, and by enriching the collection with their personal objects or photographs. In this sense, the creation of the museum was a successful local initiative. The local authorities tried to navigate within a context of rising political and social conservatism, as well as of economic austerity, which challenged their own power in the city. The changes of power in the local government did not make things easier. As a result, in the first exhibition, the museum did not challenge dominant perceptions regarding which immigrants and refugees contributed to the identity of the city as a host-city for immigrants, nor did it tackle the sensitive issues regarding Volos's contemporary multiculturalism.

Moreover, the decision about the topic of the exhibition seemed not to go against the conservatism of the new local government. The inaugural exhibition tried to shed light to a past moment, which set an example of a positive response to an economic and social crisis by underlining agency, but also political planning without challenging national homogeneity. The exhibition did not try to create references to the present which could create problems for the new conservative local authorities or their voters. For example, the exhibition did not question ethnicity as a dominant category for capturing Volos's memories and histories. In this sense, the initial aspiration for the museum to become an open space which could include more marginal voices and memories of the city was not accomplished.

On the positive side, the museum did not close its eyes to this issue. There were some discussions after the success of the first exhibition, for a second one dedicated to new migrations (it has not yet been realised). The museum also discussed involving immigrants in shaping the content of this exhibition. By doing so, the museum could become a space of encounters between immigrants and the rest of the inhabitants of Volos, something that the first exhibition had not been.

41 Since opening, the museum has been highly active. Apart from the first exhibition I described above, the permanent collection opened its doors in 2019. The official title was Volos in 10+ Stories. The number ten corresponded to five stories/themes from the pre-war period (between the nineteenth century until 1940) and five stories for the post-war era (from 1940 to present). ${ }^{42}$ The ten stories covered topics such as urban planning and infrastructure, demographics and diversification, city networks (Mediterranean, cultural, economic networks), the city in times of crisis, modernity 
and urban transformation, reconstruction, the world of work, tourism, culture and sports. Donations from residents of Volos to the museum and their stories were the basis of the collection, reflecting its participatory logic. The donations included photographs, tools, clothes etc.

Alongside the permanent exhibition, the museum organised various periodic exhibitions which I have categorised along three thematic axes: 1) the city and its artists, 2) local and regional modern history, and 3) ethnic communities in Volos. The first axis seems to have been the most popular in terms of number of exhibitions. Through archival material, these exhibitions showed the city's social and cultural life regarding food traditions, fashion and local clubs. The emphasis was on modernity and the bourgeois culture of Volos in the late nineteenth and early twentieth centuries. For example, the curator's note from the 2016 exhibition Volos, a City stressed the city's continuity, resilience and progress.

Volos, a new city, a city defined by its transition from the Ottoman settlement to a modern European city, a city developed with the arrival of refugees from Asia Minor, a city that in its short but dense history has twice experienced industrialization and deindustrialisation, a city that played a key role in the development of the labor movement in Greece, a city with a long tradition in the development of photography, a diverse city, a city - a challenge for every photographer. ${ }^{43}$

Furthermore, the same thematic axis included exhibitions promoting the work of local artists inspired by the city. These exhibitions were of established and well-known figure such as Dimitris Letsios (in 2016), a well-known photographer of the twentieth century born in Volos, and Theolphilos Chatzimichael, a naïve painter of the late nineteenth century (in 2020). But also, there were exhibitions with younger artists who approached Volos's culture in a fresh way: for example, through the industrial heritage of Volos or through new artistic materials or forms of representation, like crafting and wall painting. In this sense, modernisation, urbanism and artistic innovation seemed to be linked and were exemplified as part of Volos's continuous modernity, prosperity and success.

The second axis focused on local history and how it was included in national and world history. For instance, exhibitions showing local participation in the First and Second World Wars (in 2016) and in the Greek-Turkish War of 1897 (in 2017) were organised. Finally, the third axis was dedicated to less visible histories of ethnic communities who lived and still do in Volos, such as Jews and Greeks from Asia Minor. For example, the museum organised an exhibition concerning Jewish participation in the Greek Resistance (in 2015). The exhibition was organised in collaboration with the Jewish History Museum in Greece and the Embassy of Germany as well as the Israeli Community of Volos (Isdrailitiki Koinotita tou Volou). It should be underlined here, that the museum, as well as the university's Department of History, Archaeology and Social Anthropology paid special attention to the period of the Second World War. The museum also organises (virtual and real) walking tours dedicated to this period of the city ${ }^{44}$ Another exhibition presented the Holocaust experiences and the resistance of Jews in Greece against the Nazis. As a result, the Jewish presence was represented through its participation in national and world history, but less through its everyday urban life.

With respect to Greeks from Asia Minor, the museum organised two exhibitions dedicated to two well-known Asia Minor associations. The first (in 2016) illustrated the 
activity of the Association of Asia Minor Greeks of Nea Ionia, Iones (Polititistiki Estia Mikrasiaton Neas Ionias-Magnesias), founded in 1994. The second one (in 2017) was also linked to an association from Asia Minor, Egglezonisi (a small island near Smyrna), and depicted the activities of the association since its foundation in 1987. In this sense, refugees from Asia Minor were represented more in connection to their contribution to the city's culture through their official associations.

The inclusion of other ethnic communities, however, has remained limited. Only in a thematic exhibition, Co-Existence, the special theme launched in 2017 by the International Council of Museums (ICM) in which the Volos City Museum participated, were Roma people ${ }^{45}$ depicted through photographic material. ${ }^{46}$ The exhibition was supplemented with an educational action which introduced elementary school pupils to stories from Roma living in Volos and the wider area of Magnesia. Furthermore, there was an exhibition on Syria (Syria which I Loved) ${ }^{47}$ based on the travelogue of a wellknown Greek historian, who travelled and wrote extensively in the Black Sea and Eastern Mediterranean.

From the above, it seemed that the periodic exhibitions complemented the permanent collection in three ways. Firstly, they brought up aspects of local history which were not covered in depth by the permanent collection. Secondly, they created ties with local artists and artistic innovation. Thirdly, they connected local history with other layers and scales of history (national and world), as well as social history (for example, the life of ethnic communities). However, in terms of these ethnic communities, it appeared that the communities which had the longest presence in Volos's history (Jews and Asia Minor Greeks), and those more documented in world or national history (the Jews), were the most exhibited. Moreover, the themes of the exhibitions put emphasis on the resilience of these ethnic groups and their social integration through culture. For example, the poster for the exhibition about Iones ${ }^{48}$ was dedicated to the Church of Evaggelistria which was founded in 1969, replacing a smaller church destroyed by the earthquake of 1955. The poster showed a crowd of people going to the church. Faith, endurance and progress are three factors that connect Iones and their refugee background to the city itself.

Pelsmaeker and Van Hout underlined that the needs to offer positive immigrant representations in European museums and to struggle against xenophobia and stereotypes often led museums to over-stress a "success story." By insisting that in the end, "the immigrants made it," ${ }^{49}$ exhibit strategies normalised and erased the hardships along the way, and also turned the experience of immigration into an individual undertaking, erasing the inequalities of global and national political economies. In the Volos City Museum, the same pattern can be discerned. The city is rendered a space of modernisation and resilience despite individual misfortunes, natural disasters or historical tragedies. This strategy of emphasising reinvention does open up social and cultural histories that are often overlooked in official history, but it still avoids more sensitive political and social issues. Stories like that of Harir, which I related in the beginning of this paper, remained invisible. Nevertheless, some of these stories were recorded and can be found in the museum's Oral Histories Archive, waiting for the right moment. Until now, the refugee and immigrant flow into Volos presents an open-ended project for policy, research and representation. praxis and navigation. ${ }^{50}$ The Volos City Museum partook in European integration 
policies, and envisioned an ideal process of equal opportunities and democratisation within local administration and politics. In theory, it tried to shape a more inclusive city through the pluralisation of the narratives included in the collection. In this sense, it served the spirit of diversity and democratisation often found in many EU policies, although these policies did not target, a priori, the immigrants of Volos. Despite the above-mentioned weaknesses of the museum's early exhibitions and activities, the museum nevertheless has the potential to produce a space of communication between different memories and voices.

Behind the scenes, it seems that the museum has so far attempted to present a pluralised local history that will be accepted and supported by a few key audiences with rapidly changing views of immigration. As the museum moved towards opening, its staff and their partners had to navigate in a rapidly changing and deteriorating economic and political landscape, in which they could no longer count on the support of elected officials, or the local authorities under their direction, in a vision of "local" history as socially and ethnically inclusive. They, but also the officials and authorities, had to face long-lasting problems regarding the legal and popular reception of immigrants, but also, and maybe most importantly, they had to cope with social disillusionment regarding the country's future due to the economic recession and the collapse of the political status quo in Greece. The discussion regarding the social and cultural changes that Greece faced in the last decades and their impact on the understanding and formation of the Greek society and identity are still in their early stages.

51 Furthermore, the museum and local authorities knew they had to struggle against their own failures. In this framework, navigating the museum's mission required a nuanced understanding of how such an institution, as a city museum, works its way through a series of postponed aspirations, interruptions and compromises, as it evolves alongside new crises and the chronic problems of Greek local politics.

\section{NOTES}

1. Online: http://lecad.arch.uth.gr/demuciv/index_en.php (accessed in March 2019).

2. SCHILLER Maria, HACKETT Sarah, "Continuity and Change in Local Immigrant Policies in Times of Austerity," Comparative Migration Studies, vol.6, $\mathrm{n}^{\circ} 2,2018$, online: https:// comparativemigrationstudies.springeropen.com/articles/10.1186/s40878-017-0067-x (accessed in August 2021).

3. tAMBoRrino Rosa, "Searching for a State-of-the-Art Public Space: City Museums among Archives and Networks," Planning Perspectives, vol. 27, n 3, 2012, p. 463-473 (463).

4. GAZI Andromache, "Museia ke Episkeptes stin Epochi tis 'Viomichanias tis Mnimis"' [Museums and Visitors in the Era of "Memory Industry"], in Riki Bouschoten et al. (eds), Gefyronotas tis 
Genies. Diepistimonikotita ke Afigiseis Zois ton 210 Aiona [Bridging Generations. Interdisciplinarity and Life Stories in the $21^{\text {st }}$ Century]. Oral History Association, Volos, EPI, 2012, p. 27-43.

5. KAVANAGH Gaynor, Dream Spaces, Memory and the Museum, Leicester, Leicester University Press, 2000, p. 98.

6. o'CONNOR Justin, The Cultural and Creative Industries: A Literature Review. Newcastle upon Tyne, Arts Council of England, 2010, p. 11-49.

7. Ibid., p. 41-49.

8. PlazA Beatriz, "On Some Challenges and Conditions for the Guggenheim Museum Bilbao to be an Effective Economic Re-activator," International Journal of Urban and Regional Research, vol. 32, $\mathrm{n}^{\circ} 2$ 2, 2008, p. 506-517.

9. Online: https://www.uth.gr/panepistimio/me-mia-matia/istoria (accessed in August 2021).

10. From the old 457 municipalities and 5,318 communes, only one-fifth remain intact: 914 municipalities and 120 communes with historical significance. This last concept was quite ambiguous, leaving space for bargaining between central and local authorities over influence and power.

11. ZAIMAKIS Yannis, Koinotiki Ergasia ke Topikes Koinonies. Anaptyksi, Syllogiki Drasi ke Popypolitismikotita [Community Labour and Local Societies: Development, Collective Action and Multiculturalism], Athens, Plethron, 2002.

12. APPADURAI Arjun, Modernity at Large: Cultural Dimensions of Globalization, Minneapolis, University of Minnesota Press, 1996.

13. GAZI, "Museia ke Episkeptes stin Epochi tis “Viomichanias tis Mnimis,"' op. cit.

14. Dimoglou Aigli, Poli ke Topiki Aftodioikidi. H Periptosi tou Demou Paghason 1881-1944 [City and Local Government: A Case Study of the Municipality of Volos, 1881-1944], Corfu, Ionian University, unpublished $\mathrm{PhD}$ thesis, 2003, p. 52-153.

15. Ibid., p. 152.

16. Ibid., p. 66-76, p. 123-162.

17. Most of the immigrants interviewed as part of my research first settled in Nea Ionia as land prices and rents were lower.

18. For statistics regarding immigrant population in Greece, see online: https://ec.europa.eu/ migrant-integration/index.cfm?action=media.download\&uuid=2A853A4B-9812-

C5FD-5814BE4260729296 (accessed in August 2021).

19. "Stoixeia gia tin Poli" [Infor on the City], 2015, online: http://dimosvolos.gr/?cat=95\&lang=en (accessed in October 2015).

20. GREEK STATISTICS SERVICE, Demographic Characteristics, 2011, online: http://www.statistics.gr/ el/statistics/-/publication/SAM03/- (accessed in November 2015).

21. "I Files tou Volou" [The Tribes of Volos], Taxydromos, 3 March, 2011, online: https:// www.taxydromos.gr/Torıká/31836-oles-oi-fyles-ths-ghs-sto-bolo.html (accessed in December 2015). "Topio stin Omikhli" [Landscape in the Fog], Taxydromos, 16 December, 2013, online:

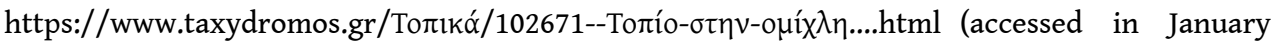
2016). "Grafeio Enimerossis Metanaston sto Volo" [Immigrant Information Desk in Volos], Taxydromos, 30 November, 2013, online: https://www.taxydromos.gr/m/m_article.php?id=100617 (accessed in June 2021).

22. Online: https://migration.gov.gr/ris/perifereiakes-monades/domes/domi-voloy/ (accessed in April 2020).

23. PYRPIRI Lydia, Khorikos Skhediasmos ke Diaxeirisi Prosfyghikon Roon [Spatial Planning and Management of Refugee Flows], Volos, University of Thessaly, unpublished MA thesis, 2017, p. 83-98.

24. Online: https://www.ethnos.gr/ellada/71567_bolos-eftasan-horis-paratragoyda-oi-protoiprosfyges-apo-ta-nisia, https://www.taxydromos.gr/topika/312139-ypodoxh-prosfygwn-me- 
dyo-opseis-sto-gymnasio-iwlkoy.html, https://www.iefimerida.gr/ellada/bolos-efthasan-oiprotoi-prosfyges-apo-aigaio (accessed in January 2020).

25. The Bulgarian immigrants were mostly female who, according to the interviews, wanted to return to their country. This orientation possibly prevented their organisation in associations.

26. scholten Peter, PoppelaARs Caelesta, "Two Worlds Apart: The Divergence of Local and National Integration in the Netherlands," Administration and Society, vol. 40, $\mathrm{n}^{\circ} 4,2008$, p. 335-357 (346).

27. In the local government elections in 2010 , Golden Dawn received $5.29 \%$ of the vote in the metropolitan municipality of Athens. In the national elections of 2012, it received $6.97 \%$ of the vote whereas, in 2009, it only received 0.29\%. See Y.P.E.S.-Election Results for 2010 and 2012 (online: https://www.ypes.gr/apotelesmata-ethnikon-eklogon/, accessed in July 2021).

28. In December 2015, however, the mayor of Volos was removed temporarily from power due to pending felonies regarding his prior career as president of the local football team.

29. ANDERSEN John, SIIM Birte, "Introduction: The Politics of Inclusion and Empowerment Gender, Class and Citizenship," in John Andersen, Brite Siim (eds), The Politics of Inclusion and Empowerment: Gender, Class and Citizenship, Basingstoke, Hampshire and New York, PalgraveMacmillan, 2005, p. 1-19.

30. PIPEROPOUlOS Panagiotis, "Ethnic Minority Businesses and Immigrant Entrepreneurship in Greece," Journal of Small Business and Enterprise Development, vol. 17, n 1, 2010, p. 139-158; SKLAVOU Theodota, Politistiki Politiki, Diktya Politismou kai Politistikes Drastiriotites: Politistiki Politiki tis Topikis Aftodioikisis. [Cultural Policy, Cultural Networks and Cultural Activities: Cultural Politics of the Local Government], Patras, Hellenic Open University, unpublished MA thesis, 2019; SKAMNAKIS Christoforos, POLYzoIDIS Periklis, "Migrant Integration Councils (MICs): The Incomplete Functioning of an Important Institution for the Local Government," Social Cohesion and Development, vol. 8, $\mathrm{n}^{\circ}$ 2, 2016, p. 165-176.

31. PENTAZou Ioulia, "Sxediazontas to Mouseio tis Polis tou Volou. H Yposxesi kai oi Prokliseis ton Proforikon Martyrion" [Designing the Volos City Museum: The Promise and Challenges of Oral Testimonies], in Dimitra Labropoulou (ed.), I Mnemi Afigeitai tin Poli. Proforiki Istoria ke Mnemi Astikou Khorou [Memory Narrates the City: Oral History and Memories of Urban Space], Athens, Plethron, 2016, p. 35-51 (38).

32. "Ta Egainia tou Mouseiou tis Polis tou Volou" [The Inauguration of the City Museum in Volos], TRT Channel Greece, 24 December 2014, online: https://www.youtube.com/watch? v=XPCkCc5hxmo_(accessed in December 2015).

33. "To Mouseio tou Volou anoigei tis Portes tou" [The Museum of the City of Volos Opens its Doors], Nafteboriki, 31 December 2014, online: http://www.naftemporiki.gr/story/896701/tomouseio-tis-polis-tou-bolou-anoikse-tis-pules-tou-sto-koino (accessed in October 2015).

34. DIMOgLou, Poli ke Topiki Aftodioikidi, op. cit.

35. PAPAGIANITSIS Georgios, Astiki Anasygrotisi, Ikonomiki Anaptyksi ke Agora Akiniton. I Periptosi tis Periokhis "Palaion," stin Poli tou Volou [Urban Reconstruction, Economic Development and the Real Estate Market: The Case of Palea in the City of Volos], Volos, University of Thessaly, unpublished MA thesis, 2009.

36. The opening of the permanent collection took place in 2019.

37. Online: https://www.elculture.gr/blog/volos-10-istories-mouseio-polis-tou-volou/ (accessed in February 2020).

38. Online: https://www.kathimerini.gr/culture/arts/1063598/to-paradeigma-toy-moyseioy-tispolis-toy-voloy/ (accessed in February 2020).

39. PelsmaeKers Katja, VAN hout Tom, "People on the Move: How Museums De-marginalize Migration," Social Semiotics, vol. 30, $\mathrm{n}^{\circ} 4,2020$, p. 607-624.

40. Migration is often a popular theme for urban museums due to the history of migration flows in European cities. 
41. Teloglou Tassos, "I Ptosi tou Volou" [The Fall of Volos], Protagon, 2014, online: https:// www.protagon.gr/epikairotita/politiki/i-ptwsi-tou-volou-33686000000 (accessed in June 2020).

42. Online: https://e-thessalia.gr/aigli-dimogloy-mia-ekthesi-apo-voliotes-gia-ton-volo/ (accessed in June 2021).

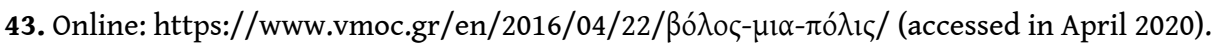

44. Online: http://www.vmoc.gr/sw2/sw_home.html (accessed in April 2020).

45. Central Greece, Magnesia and Volos host several Roma settlements involved in agriculture as well as trade.

46. Online: https://e-thessalia.gr/stigmiotypa-apo-ti-zoi-ton-tsinganon-ston-volo/ (accessed in February 2020).

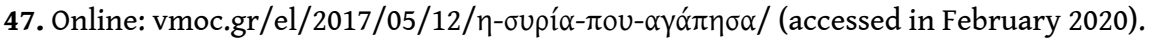

48. Online: http://www.vmoc.gr/wp-content/uploads/2020/05/Image00008.jpg (accessed in February 2020).

49. Pelsmaekers, VAn HOUt, People on the Move, op. cit., p. 612-621.

50. VIGH Henrik, "Motion Squared: A Second Look at the Concept of Social Navigation," Anthropological Theory, vol. 9, $\mathrm{n}^{\circ}$ 4, 2009, p. 491-438.

\section{ABSTRACTS}

City museums tend to be identified with the gradual democratisation of memory against nationalist and essentialist discourses through the pluralisation of histories included in their collections. My paper examines the context in which the Volos City Museum was conceived, constructed and opened in 2015. The EU's gradual decentralization and its connection to the diversification of European societies through migration, made necessary the integration of immigrants at the local level. These changes had an impact on Volos and were stepping-stones for the foundation of the museum. This paper is based on fieldwork linked to the new museum's opening, as well as an examination of its activities and agenda.

Les musées de la ville ont tendance à intégrer dans leurs collections la pluralisation des histoires et à contribuer ainsi à une démocratisation progressive de la mémoire, à l'opposé de discours nationalistes et essentialistes. Mon article examine le contexte dans lequel le musée de la ville de Volos a été conçu, construit et a ouvert ses portes en 2015. La décentralisation progressive de l'Union européenne, en lien avec la diversification des sociétés européennes par la migration, a fait de l'intégration des immigrés au niveau local une nécessité. Ces changements ont eu un impact sur la ville de Volos et ont conduit à la fondation du musée. L'article est basé sur un travail de terrain dans le cadre d'un projet de recherche lié à l'ouverture du nouveau musée et sur un examen des activités et de l'agenda du musée.

\section{INDEX}

Mots-clés: musée de la ville, mémoire, immigration, Balkans et ex-Union soviétique, Asie Keywords: city museum, memory, integration, immigration, Balkans and former Soviet Union, Asia 
AUTHOR

ELENI SIDERI

University of Macedonia, Greece

elasideri[at]uom.edu.gr 